\title{
BPI Fold-Containing Family A Member 1
}

National Cancer Institute

\section{Source}

National Cancer Institute. BPI Fold-Containing Family A Member 1. NCI Thesaurus. Code C118518.

BPI fold-containing family A member 1 (256 aa, $\sim 27 \mathrm{kDa}$ ) is encoded by the human BPIFA1 gene. This protein may be involved in innate immunity in the upper respiratory tract. 